\title{
Theoretical and Interpretative Approaches to the Dictionary of Moravian and Silesian Anoikonyms ${ }^{1}$
}

\author{
Milena ŠipKová \\ Department of Dialectology, Institute of the Czech Language of the AS CR, v. v. i. \\ Veveři 97, CS-60200 Brno, sipkova@iach.cz
}

\begin{abstract}
SCN III/1 [2010], 172-182
Slovar moravskih in šlezijskih anojkonimov, sestavljen v tradicionalni natisnjeni in digitalni obliki, je vzporednica Slovarju imen manjših čeških krajev (Dictionary of Minor Place Names in Bohemia). Predstavlja (1) enkratno gradivo (pokriva $96 \%$ ozemlja) in (2) teoretični in metodološki koncept češke onomastične šole. Slovar ponuja analizo gradiva in razlago imen, sestavljenih iz mnogih narečnih oblik.

The Dictionary of Moravian and Silesian Anoikonyms, compiled in both a traditional "paper" and a digital form as a parallel to the Dictionary of Minor Place Names in Bohemia, has two priorities: 1. unique material (covering $96 \%$ of the territory), 2. theoretical and methodological conception that represents the Czech onomastic school. The Dictionary aims to provide both a material analysis and an interpretation of names comprising many dialectal forms.
\end{abstract}

Ključne besede: slovar, anojkonim (ime manjšega kraja), onomastika, narečje, jezikovna karta

Key words: dictionary, anoikonym (minor place name), onomastics, dialect, language map

The present article aims to introduce the new (digital) project of the Dictionary of Moravian and Silesian Anoikonyms (Minor Place Names) which is being compiled at the Department of Dialectology of the Institute of the Czech Language of the Czech Academy of Sciences in Brno (as a parallel to the

\footnotetext{
${ }^{1}$ This paper has been compiled on the basis of a grant by the Czech Science Foundation, No 405/08/0703 Slovník pomistních jmen na Moravě a ve Slezsku II (teoretické a interpretační aspekty).
} 
Dictionary of Minor Place Names in Bohemia (Matúšová, 2005), compiled at the Department of Onomastics of the same institute in Prague).

To clarify the situation, it should briefly be mentioned here that historically, the Czech Republic is composed of three territories - Čechy (Bohemia), Morava (Moravia) and the Czech part of Slezsko (Silesia). At present, it is divided into 14 newly created regions, the historical tradition is, nevertheless, still alive and finds reflection also in the project of the Dictionary of Moravian and Silesian Anoikonyms. The capital of the Czech Republic and of historic Bohemia is Prague, the centre of the territory called Moravia is Brno. From a linguistic point of view it is significant that the regions of Moravia and Silesia still show great dialectal differentiation and that the territorial dialects there have been well preserved. The situation in Bohemia is rather different: the dialects were levelled and they have only been preserved at the outskirts of the region. This situation, naturally, finds reflection in the language form of anoikonyms.

Historical territories in the contemporary Czech Republic ${ }^{2}$

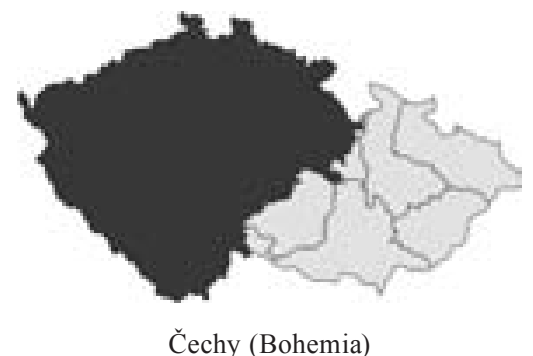

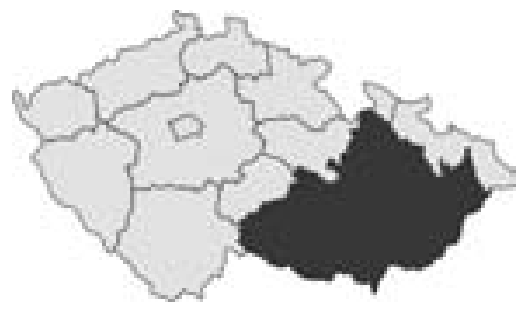

Morava (Moravia)

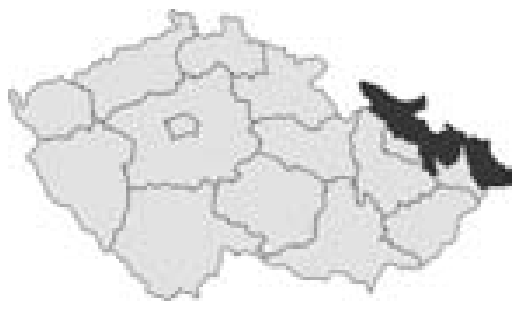

Slezsko (Silesia)

The work on the Dictionary of Moravian and Silesian Anoikonyms began in 2005, after the completion of the most important Czech dialectological project - the five-volume Ćeský jazykový atlas [Czech Linguistic Atlas] (1992-2005; the sixth volume entitled Dodatky [Supplements] is at the printers) providing

\footnotetext{
${ }^{2}$ http://en.wikipedia.org/wiki/Moravia [2009-08-31]
} 
nearly 1,600 language maps and commentaries which give a complete picture of the geolinguistic differentiation of the Czech language. ${ }^{3}$

To compile the Dictionary, we received financial support from the Czech Science Foundation. The decision to process the Moravian and Silesian anoikonymic material was, nevertheless, influenced by a multitude of factual reasons as well. The most important are the following four:

(1) The fact that the current collection of Moravian and Silesian anoikonymic material is relatively complete. It comprises almost a quarter of a million (nearly 225000 ) records from almost $96 \%$ of the territory under investigation. The material was collected in three ways: correspondence inquiry (the main source $)^{4}$, direct field work, diploma and doctoral theses ${ }^{5}$. The survey work in Moravia and Silesia was carried out mainly in 1965-1989 as an integral part of the nation-wide inquiry, and it is one of the largest projects of Czech (as well as Slavic) onomastics. It aimed at acquiring a complete list of anoikonyms from the cadastre of each village in those parts of Moravia and Silesia that were permanently inhabited by those of Czech nationality. (In the area of Český Těšín, near the Polish border, also of Polish nationality.) Villages recording former prevalence of inhabitants of German nationality ${ }^{6}$ were not included, nor were localities newly settled after 1945 . The material is stored on paper filing cards and is located at the Brno Department of Dialectology.

(2) The fact, that a parallel dictionary for the region of Bohemia is being published by our colleagues in Prague: Slovnik pomistnich jmen v Čechách [Dictionary of Minor Place Names in Bohemia] (J. Matúšová (ed.): (A) 2005, (B-Bau) 2006, (Bav-Bíd) 2007, (Bíg-Bož) 2008).

${ }^{3}$ The first three volumes deal with lexis, the fourth volume with morphology, and the fifth volume with phonology and syntax. The Supplements will also include two CDs of audio recordings of dialect speech (one for Bohemia, one for Moravia and Silesia) and their transcriptions as well as a fairly complete bibliography of Czech dialectology starting from 1968. Dialectological literature published before this year can be found in the monograph by Jaromír Bělič, 1972: Nástin české dialektologie [Outline of Czech Dialectology]. Praha: Státní pedagogické nakladatelství.

${ }^{4}$ Field work was carried out under the head of Místopisná komise ČSAV and was initiated by Vladimír Šmilauer. Concerning the beginning of this project cf. František Matějek (1965): K počátkům výzkumu pomístních jmen na Moravě [On the beginnings of anoikonymic research in Moravia]. Zpravodaj mistopisné komise ČSAV 6. 218-219.

${ }^{5}$ More than two hundred diploma theses were written. Their aim was the systematic investigation of the rapidly changing anoikonymy in the villages as well as research into the new ways of denomination, arising in dialects. Concerning the metodology of diploma theses cf. Rudolf Šrámek (1974): Metodický návod k výstavbě diplomové nebo seminární práce $\mathrm{z}$ onomastiky [Methodical instructions on the construction of diploma or seminar onomastic work]. Zpravodaj mistopisné komise ČSAV 14. 202-211.

${ }^{6}$ The data were based on the Statistický lexicon obcí v zemi Moravskoslezské [Statistic Lexicon of Villages in the Moravian-Silesian Land] (1935). Praha: Orbis and on Ladislav Hosák and Rudolf Šrámek (1970, 1980). 
(3) The fact that a project of an anoikonymic dictionary is also being prepared in neighbouring Slovakia; for comparative studies the Moravian-Silesian gap would undoubtedly have been quite noticeable.

(4) The idea of compiling a dictionary of anoikonyms was also influenced by the elaborate theoretical and methodological conceptions of the Czech onomastic school (e.g. Milan Harvalík, Ivan Lutterer, Libuše Olivová-Nezbedová, Jana Pleskalová, Rudolf Šrámek, Pavel Trost). ${ }^{7}$ Czech onomastics has lexicographically processed material both in the sphere of place names (e.g. Profous and Svoboda 1947-1960; Hosák and Srámek 1970-1980), and in the sphere of anthroponyms (e.g. Beneš 1962, Svoboda 1964, Moldanová 1983, Knappová 1989, Pleskalová 1998, Komárek 2000); at present, it is necessary to process the third sphere of names, i.e. the names of uninhabited objects. In Czech onomastics, in accordance with the terminology approved by the Terminological Committee of the International Council of Slavic Onomastic Science (Osnoven sistem i terminologija na slovenskata onomastika, 1983) they are called anoikonyms, and their core is represented by what in different onomastic schools has been referred to as minor place names, field names, Flurnamen, microtoponyms, etc. In the Dictionary of Moravian and Silesian Anoikonyms, the names of uninhabited objects, i.e. the names of fields, meadows and forests, hills and mountains, waters (rivers, brooks, ponds) and communications, are processed. The Dictionary, however, also comprises the names of solitary trees, stones, rocks, (stone) crosses and other points used for orientation as well as the names of local parts, isolated houses and hamlets. Though these are inhabited, they often assume the original anoikonym, e.g. Vinohrady 'vineyards', Háj 'grove/ forest'.

It is Rudolf Šrámek and Jana Pleskalová, who deserve the main credit for collecting of the material as well as its sorting and lexicographic advance preparation (e.g. Šrámek 1995a: 158-181; 1995b: 230-242; 2001: 126-140). The creation of the onomastic theory found reflection in the interpretation of anoikonymic material, especially in the works by J. Pleskalová and in her description of the Moravian and Silesian anoikonymic material from the structural and relational point of view (Pleskalová 1992; also other literature can be found there). Rudolf Šámek and Jana Pleskalová are the authors of the Heslár ke Slovníku pomístních jmen na Moravě a ve Slezsku [Inventory of Headwords of the Dictionary of Moravian and Silesian Anoikonyms] (1993, in manuscript).

We have already mentioned that one of the reasons for compiling the Dictionary was the fact that the Dictionary of Minor Place Names in Bohemia is being published in Prague. This article cannot explain in detail why there are two anoikonymic dictionaries being compiled on the relatively small territory of the Czech Republic. In short, this is due to the following reasons: differences in conceptions of the two projects, the differences in the time when they started; the fact that the Czech material has been stored in Prague while the

\footnotetext{
${ }^{7}$ For information on the achievements of Czech onomastics see Rudolf Šrámek, 2007.
} 
Moravian and Silesian material has been stored in Brno; development of the digital technology and possibilities of its use. Progress in digital technique and technology enables us to use digitization not only as an instrument to store (register) the language material but also (owing to an original programme invented specially for our Dictionary) to create - in addition to the classical "paper" dictionary - a parallel interactive digital one (cf. the paper of L. Čižmárová elsewhere in this volume).

The Dictionary of Moravian and Silesian Anoikonyms aims to introduce the complex anoikonymic material from the (eastern) half of the territory of the Czech Republic in a broad and many-sided view and in this way to mediate the synchronic systemic picture of Moravian and Silesian anoikonymy from the middle of the $20^{\text {th }}$ century. As for its age, the material is quite heterogenous as it comprises anoikonyms dating back to pre-Slavic period (for instance, the name of the river Morava, which gave name to the whole region) through the Middle-Ages (e.g. Čarodějka, 'sorceress', a hill in Kunín, known from witchhunting in the Middle Ages and dating back to 1583) to anoikonyms that arose quite recently (e.g. Drůbežárna 'poultry farm', denominating mainly buildings and mostly dating to the $1950 \mathrm{~s}$, or Bam, which in fact is the abbreviation for the railway line in Russia called "Bajkalsko-amurská magistrála" [Baikal-Amur Mainline] which was finished in 1980s; it is an ironic name created by local workers, denominating a wide road in the forest used for the transportation of stone from a nearby quarry.

It should be emphasized that the onomastic interpretation of the anoikonyms is not limited to etymology or word formation; the Dictionary aims to give both the material analysis and the interpretation of names, i.e. to describe the names, their origin, and structural formation, as well as their motivation, and relation to objects, and to give their geographic (and frequency) distribution. In this way, it represents a new type of anoikonymic dictionary. Special attention is given to the problem of numerous dialectal forms of names, which - together with the need to reflect the profound dialectal specification of the Moravian and Silesian anoikonymic material but not to impede its perception at the same time - opens the question of a proper degree of lemmatization. Should, for instance, the Moravian dialectal form Na Vávrové skalce [on Vávra's little rock] (with the adjectival inflection of the possessive adjective) or the common (in eastern parts of Moravian dialects unused, but in our material - perhaps as a result of a desire to seem formal or educated - registered) form Na Vávrový skalce, both corresponding to the standard and codified (but unused) form $\mathrm{Na}$ Vávrove skalce (with the name form of the possessive adjective) be registered? There must be a compromise as it is impossible to register all the dialectal forms and nuances. And the further toward the standard form we go, the more the anoikonym looses its original character. Application of the principle of lemmatization and standardization on all levels would cause the loss of a substantial part of information of the anoikonym's actual form, especially in indirect cases, because in these cases, the nominative as the basic noun form of a headword is not often easy to reconstruct. The material, unfortunately, does not reflect the 
local dialect authentically; though the informants were asked and instructed to do so: numerous anoikonyms were deliberately „standardized“, however, they often stopped halfway, e.g. U spálenyho boka (with the dialectal change $u>o$ realized only in the noun buk 'oak', not within the preposition $u$ ).

It is important to note that the material was collected just in time: because of collectivization and distinctive changes in both agriculture and village life in general, many anoikonyms are no longer used, many disappeared, and the young generation does not use them because they do not need them. Our material therefore is of historical value as well: it is an important source of regional history. Above others, it bears witness, for instance, to the a) conditions of former settlement (e.g. the anoikonym $\mathrm{Na}$ Ždirku denominates a place in the forest that arose as a result of burning activity; in the wooded regions the new colonists had to "vyžd'áritt", 'burn out', the forest and cultivate the land; names with this root are typical for the western parts of Moravia; the anoikonym Losky denominates property gained by "losování" 'drawing lots', i.e. in a lottery; the name Familie/Famelie indicates the property that - after the abolition of the churches' and other large landholders' farms at the end of the $18^{\text {th }}$ century - was divided among certain families to hereditary rent; b) the legal situation and property ownership (e.g. the anoikonym Společnica informs us of the existence of a community property farmed in common, Panský les reveals that the holder of the denominated object (forest) was a lord, the anoikonyms Pospiśsilu les / Doležilü les / Kuběnků les / Navrátilů les give us a sequence of the owners of the same forest in the village of Bohdíkov SU, i.e. Pospíšil, Doležil/Doležel, Kuběnka, Navrátil); c) historical and local events (e.g. Napoleonova lípa 'Napoleon's linden tree' denominates a linden tree, under which - according to the folk narration - Napoleon Bonaparte, the Austrian emperor František I and the Russian tsar Alexander met and signed the armistice after the battle of Austerlitz in 1805), etc.

Many anoikonyms give testimony to the existence of villages now extinct, e.g. objects called Babin (field, forest, meadow) in the Žd'ár region bear the name of the extict village Babín (vanished in the $15^{\text {th }}$ century). As we can see, the knowledge of the extinct village can live for centuries and its name can be transferred to more objects.

In particular, the anoikonyms help with research into the history of our mother tongue, with etymological explanations and with the study of interlanguage contacts. The anoikonyms are recorded in the speech of the respective region, primarily in the spoken form. They preserve mainly features typical for the dialect of the given region, cf., for instance, the Moravian and Silesian dialectal forms of anoikonyms with the roots -dub-/-doub-: $U d u b u, U$ dobo, $O$ doba, O dobu, Ho dobo, Ho dubo, ... all 'near an oak'; Doubky, Dóbke, Dúbky, Dúbka, Dymbky, all 'oaks'; forms with the characteristic soft "Moravian" inflection (Frankova suširña, Na barvirni, V lesi); the dialectal form of possessive adjectives in $-\stackrel{i}{j}$ (corresponding to the standard language suffix $-u v v$ ), typical especially for the southern half of Moravia: Babušikỉj kopeček 
'Babušík’s little hill', Sókupuj háječek 'Soukup's grove'; the suffix -ovice, used to denominate property (especially isolated farms and houses) and derived from the names of the owners: Bednarovice, Bendovice, ...; this suffix is typical for the region of eastern Silesia, etc. The anoikonyms also register phenomena that are untypical for the dialects in Moravia and Silesia, e.g. the formation of possessive adjectives by suffix - $\stackrel{u}{v}$, -ova, -ovo, derived from names (or even appellatives) of adjectival origin (this type does not occur in the standard language): the anoikonym Hlásnovo pole 'Hlásný's field' denominates a field that used to belong to the local watchman (hlásný 'watchman'); the type spreads from the dialects in eastern Bohemia to the dialects in western Moravia ${ }^{8}$ ). The anoikonyms also typically provide knowledge of the old lexis, they preserve words that mostly are not used any more, or words that have vanished, e.g. in the names Debřa/Debrice, ... (deb̌r 'elongated valley'), Zbel/Gbel/Kbel/Bel, ... (referring to the Old Czech stbel 'well').

The territory of Moravia and Silesia has always been an area of close contact of different ethnic groups and languages. Especially the language, social and cultural contact with the German border regions found reflection in numerous anoikonyms of German origin, mostly adapted to Czech, e.g. Na Bambizi ( $<$ Baumwiese 'meadow with trees'), Bandehýbl $(<$ bei dem Hügel 'near the little hill'), Cindolina ( $<$ Zündholzlehne $<$ Zündholz 'kindling wood, match', Lehne 'slope'), Birla (< maybe Bürlein 'burden, difficulty'; name for a field in a slope, with a gritty, stony soil that might have been infertile or difficult to cultivate), etc. In accordance with the conception of our dictionary, within the so-called summary entries not only the Czech but also the German roots (stems, bases, etymons) will be listed, e.g. acker(l)-, acht(el)-, -bach-/-pach-, -baum-, -berg-/-berk-/-perk-, breit-, -brenn-/-brannt-/-brand-, burg-/-burk-/purg-/-purk, -dorf-, eich(el), -eis-, end(e)-, -engel-, -erb-, -feld-, ..., -schule-, giving brief etymological, onomastic and dialectal information and registering the headwords under which the respective anoikonyms are listed. Also other language contacts can be traced in our material, e.g. contact with Polish (cf. the name Grobla for 'dike' and the local part, registered only from the region of Karviná near the Polish border; dialectal word grobla 'dike, jetty') or Slovak (cf. Falatky, field in the Uherský Brod district; Slovak dial. falatok 'piece of land'; through Slovak from Hungarian, or Hafernik, hill in the Frýdek-Místek district; dial. hafera $a^{9}$ 'blueberry', through Slovak from Romanian ${ }^{10}$ ). A special layer is then represented by anoikonyms reflecting the appellatives that came to Moravia and Silesia as a result of the so-called Carpathian (Wallachian) colonization, e.g. Grún̆ (usually a forest, hill; dial. grún̆"11 'slope, hill-side,

\footnotetext{
${ }^{8}$ Olivová-Nezbedová, 1993 and Cuřín, 1964.

${ }^{9}$ Concerning the geographical distribution of the appellative cf. Czech Linguistic Atlas 2 (1997, 232-233).

${ }^{10}$ See Machek, 1971.

${ }^{11}$ Concerning the geographical distribution of the appellative cf. Czech Linguistic Atlas 2 $(1997,303,478)$.
} 
hill'), Grapa/Drapa/Zdrapa (mostly a hill, forest, field; dial. grapa ${ }^{12}$ 'ravine, steep slope'), Brynzička (glade in the Zlín district; from brynza 'sheep cheese').

From the estimated number of 225,000 items almost half of the material $(100,000)$ has already been digitized. At the same time, the first part of the Dictionary has been compiled. From the estimated number of nearly 30,000-33,000 entries, more than 6,000 have been completed. An integral part of the entries will be (digital) maps showing the geographical distribution and frequency of the anoikonyms represented by the respective headwords.

I would like to conclude my paper with just a brief demonstration of the aforementioned theoretical and methodological guidelines using the example of two entries: ALPY and BALKÁN. (The index numbers mean the frequency.)

\section{ALPY plt.}

\section{1+2 I a Alpy field Domašov BO}

3 The anoikonym arose through the process of transformation of the name of the mountain range Alpy [the Alps]. It is used as a figurative name for a field with "numerous gaps and lowlands created during the floods". For similar motivation cf. KARPATY, HIMALÁJE etc.

$$
\text { IPJČ }{ }^{13} \text { Alpy } p l \text {. }
$$

\section{BALKÁN $\mathbf{N}_{11} \mathbf{m}$.}

1 I a $B-n_{7}$ b $N a B-n \check{e}_{4}$

2 a field 4 , local part ${ }_{2}$, hill, forest $\mathbf{b}$ forrest $_{2}$, pub, fields

3 The anoikonym Balkán arose as a metaphoric name on the basis of various connections with the Balkan peninsula. The anoikonyms mostly come from the period of the Balkan wars (1912-1913) or shortly thereafter. They were partly motivated by these wars: "the stone was blasted-off there" (forest and field at Luka nad Jihlavou JI), "it looked there like during the war in the Balkans" (field at Tylovice VS), partly by the remoteness/ distance (the objects were usually located at the end of the cadastre, e.g. the local part at Hodslavice NJ: "the name arose during the first Balkan war in 1912 and indicates a row of houses on the Upper End in the direction to the fields"), possibly the by the form of the landscape (the hill at Dětkovice VY). - Similar motives are manifested also in prepositional names (only with the preposition $n a$ [on]). The anoikonym Na Balkáné in Jundrov BM indicates a former pub (perhaps on the basis of the noisy atmosphere); the fields at Horní Dubenky JI, situated in a hilly terrain, got their name in 1918, because their owner "spent Word War I as a soldier in the Balkans". For some of these motivations, especially the distance, cf. AMERIKA, AFRIKA, ČÍNA, KOREA etc.

The anoikonyms are sporadically registered all over the region of Moravia.

IPJČ

${ }^{12}$ Concerning the geographical distribution of the appellative cf. Czech Linguistic Atlas 2 $(1997,301,306)$.

${ }^{13}$ The abbreviation is used for the Index pomístních jmen v Čechách [Inventory of Anoikonyms in Bohemia] and indicates that the headword has been registered there. 


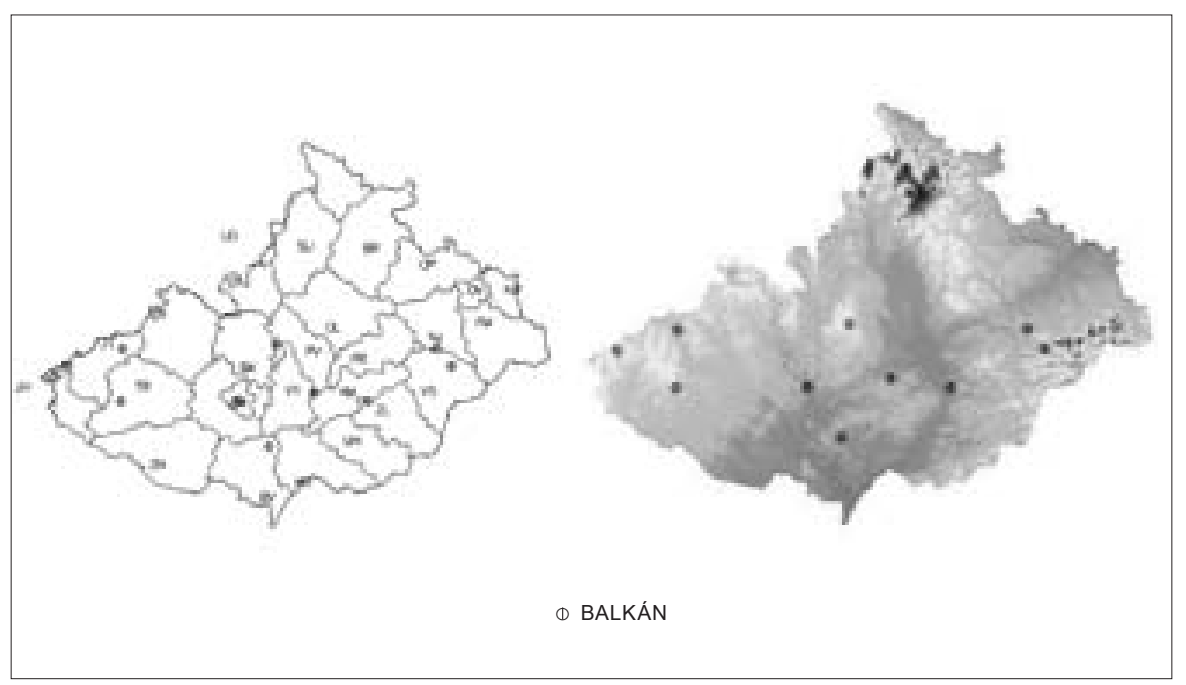

\section{BIBLIOGRAPHY}

Český jazykový atlas [Czech Linguistic Atlas]. 1992-. $1^{\text {st }}$ volume 1992, $2^{\text {nd }}$ volume $1997,3^{\text {rd }}$ volume 1999, $4^{\text {th }}$ volume $2002,5^{\text {th }}$ volume 2005. $6^{\text {th }}$ volume (Supplements) at the printers. Praha: Academia.

Jan BENEŠ, 1962: O českých př́ijmenich [On Czech Surnames]. Praha: Nakladatelství ČSAV.

František CUŘÍN, 1964: Historický vývoj označování rodiny a rodinné př́slušnosti $v$ českých nářečích [Historical development of designations of family and family relationships in the Czech Dialects]. Praha 1964: Nakladatelství Československé akademie věd.

Ladislav HOSÁK and Rudolf ŠRÁMEK, 1970: Mistni jména na Moravě a ve Slezsku [Moravian and Silesian Place Names]. A-L. Praha: Academia.

- -, 1980: Místní jména na Moravě a ve Slezsku [Moravian and Silesian Place Names]. $M \check{Z}$. Praha: Academia.

Miloslava KNAPPOVÁ, 1989: Rodné jméno v jazyce a společnosti [Family Name in the Language and Society]. Praha: Academia.

Karel KOMÁREK, 2000: Osobni jména v českých biblich [Personal Names in Czech Bibles]. Olomouc: Votobia.

Jana MATÚŠOVÁ (ed.), 2005: Slovnik pomístnich jmen v Čechách [Dictionary of Minor Place Names in Bohemia] I (A). Praha: Academia.

- - (ed.), 2006: Slovník pomístnich jmen v Čechách [Dictionary of Minor Place Names in Bohemia] II (B-Bau). Praha: Academia. 
- - (ed.), 2007: Slovník pomístnich jmen v Čechách [Dictionary of Minor Place Names in Bohemia] III (Bav-Bid). Praha: Academia.

- - (ed.), 2008: Slovnik pomistnich jmen v Čechách [Dictionary of Minor Place Names in Bohemia] IV (Bíg-Bož). Praha: Academia.

- - (ed.), 2009: Slovník pomistnich jmen v Čechách [Dictionary of Minor Place Names in Bohemia] V (Bra-Buc). Praha: Academia.

Václav MACHEK, 1971: Etymologický slovník jazyka českého [Etymological Dictionary of Czech Language]. Praha: Academia.

Dobrava MOLDANOVÁ, 1983: Naše př̉imení [Our Surnames]. Praha: Agentura Pankrác.

Libuše OLIVOVÁ-NEZBEDOVÁ, 1993: Přídavná jména přivlastňovací tvořená př́íponou - ův z adjektivních př́ijmení [Possessive Adjectives formed by the Suffix

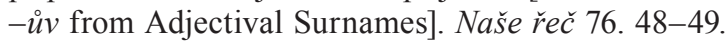

Osnoven sistem i terminologija na slovenskata onomastika [Basic System and Terminology of Slavic Onomastics], 1983. Skopje: Makedonska akademija na naukite i umetnostite.

Jana PLESKALOVÁ, 1998: Tvoření nejstaršich českých osobnich jmen [Formation of the Oldest Czech Personal Names. Brno: Masarykova univerzita ...].

- -, 1992: Tvoření pomístních jmen na Moravě a ve Slezsku [Formation of Anoikonyms in Moravia and Silesia]. Jinočany: $\mathrm{H} \& \mathrm{H}$.

Jana PLESKALOVÁ and Rudolf ŠRÁMEK, 1993: Heslář ke Slovniku pomístních jmen na Moravě a ve Slezsku [Inventory of Headwords of the Dictionary of Moravian and Silesian Anoikonyms]. Brno: ÚJČ AV ČR (manuscript).

Antonín PROFOUS and Jan SVOBODA, 1947-1960: Místní jména v Čechách [Place Names in Bohemia] I-V. Praha: Nakladatelství Československé akademie věd.

Jan SVOBODA, 1964: Staročeská osobni jména a naše př́jmení [Old Czech Personal Names and our Last Names]. Praha: Nakladatelství Československé akademie věd.

Rudolf ŠRÁMEK, 1995a: Onomastická lexikologie [Onomastic Lexicography]. Manuál lexikografie [Manual of Lexicography]. Ed. František Čermák and Renata Blatná. Jinočany: H\&H. 158-181.

- -, 1995b: Ukázka lexikografického zpracování pomístních jmen z Moravy a Slezska [Specimen of the lexicographic treatment of anoikonyms from Moravia and Silesia]. Acta onomastica, 36, 230-242.

--, 2001: Pomístní jména s etymonem -plan- na Moravě a ve Slezsku [Anoikonyms with the etymon -plan- in Moravia and Silesia]. Profesor Hauser jubilujicí. Sborník př́íspěvků ze semináře konaného 10. 4. při příležitosti 80. narozenin prof. PhDr. Přemysla Hausera, CSc. Ed. Květoslava Klímová and Helena Kneselová. Brno: Masarykova univerzita. 126-140.

--, 2007: Onomastika [Onomastics], Kapitoly z dějin české jazykovědné bohemistiky [Chapters from the History of the Czech Bohemian Studies in Lingustics]. Eds. Jana Pleskalová et al. Praha: Academia. 377-425. 


\section{TEORETIČNI IN INTERPRETATIVNI PRISTOPI V SLOVARJU MORAVSKIH IN ŠLEZIJSKIH ANOJKONIMOV}

Članek predstavlja projekt Slovar moravskih in šlezijskih anojkonimov (imen manjših krajev) (Dictionary of Moravian and Silesian Anoikonyms (Minor Place Names)); anojkonime je zbral Oddelek za dialektologijo inštituta češke akademije znanosti v Brnu, in sicer kot vzporednico Slovarju imen manjših čeških krajev (2005-). Projekt spoštuje tradicijo delitve Republike Češke na tri zgodovinska ozemlja, Češka (Bohemia), Moravska (Moravia) in češki del Šlezije (Silesia), ter veliko razliko med moravskimi in šlezijskimi narečji.

Slovar se pripravlja v tradicionalni in digitalni obliki. Ima dve izhodišči: (1) enkratno, relativno popolno gradivo (skoraj 225.000 posnetkov s skoraj $96 \%$ raziskanega ozemlja); (2) teoretični in metodološki koncept, ki predstavlja češko onomastično šolo. Slovar želi razkriti raznolikost anojkonimov (njihovo strukturo, zvezo z objektom, geografsko distribucijo, motivacijo v procesu imenovanja) - gre za nov tip anojkonimnega slovarja. Posebna pozornost je namenjena številnim narečnim oblikam anojkonimov, kar odpira predvsem vprašanje ustrezne lematizacije.

Na Moravskem in v Šleziji so se v zgodovini vedno prepletali jezikovni vplivi različnih etničnih skupin. V gradivu so navedeni zlasti anojkonimi nemškega izvora, npr. $\mathrm{Na}$ Bambizi ( $<$ Baumwiese), Bandehýbl ( $<$ bei dem Hügel), zaslediti pa je mogoče tudi druge stike, npr. s poljščino (Grobla) ali slovaščino (Falatky, preko slovaščine iz madžarščine; Hafernik, preko slovaščine iz romunščine). Posebno plast predstavljajo anojkonimi, ki so rezultat t. i. karpatske (Wallachian) kolonizacije, npr. Grún̆, Grapa/Drapa/Zdrapa, Brynzička itd.

Digitalizirana je bila že skoraj polovica od približno 225.000 enot, hkrati je bil zbran prvi del slovarja. Izdelanih je bilo več kot 6.000 od približno 33.000 vseh gesel. 